\title{
Military Geography
}

\section{Colonel J. F. Maurice C.B., p.s.c.}

To cite this article: Colonel J. F. Maurice C.B., p.s.c. (1892) Military Geography, Royal United Services Institution. Journal, 36:172, 607-616, DOI: 10.1080/03071849209417654

To link to this article: http://dx.doi.org/10.1080/03071849209417654

\section{曲 Published online: 11 Sep 2009.}

Submit your article to this journal

LII Article views: 9

Q View related articles $₫$ 


\section{OHto \\ or max

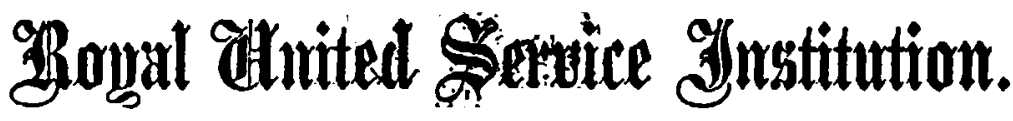

VoL. XXXVI.

JUNE, 1892.

No. 172.

[Monthly Ienue.]

Friday, April 29, 1892.

Lieutexant-Gexeral Sir ROBERT BIDDDLPH, K.C.M.G., C.B., Director-General of Military Fducation, in the Chair.

\section{MILITARY GEOGRAPHY.}

By Colonel J. F. Madrice, C.B., p.s.c., Professor of Military Art and History, Staff College.

Tre subject with which the Council of this Society has asked me to deal this afternoon is a large onc. I fear a littlo lest, interesting and important as it is to all soldiers in itself, the mere sketch of its character which our time permits may make it dull for want of illustration. I shall endeavour to aroid that as far as I can, but after all a catalogue of the most interesting books in the world would be dreary rending to those who knew nothing of their contents. The one consolation, therefore, that I hare in speaking to for is that I am sure that that is by no means the case. You wish mo rather to be in the position of the man who, in merely naming Dickens' works, saggests the pleasures you bave derired from the humour of the "Pickwick Papers" and the pathos of "Dombey;" in naming Thackeray brings before you a gallery of familiar faces. You wish $m e$, in fact, rather to express factu familiar to us all than to introduce you to anything that is very now, and must bo dreary if it does not receive illustration from your own knowledgo and experience.

Military Geography, then, as I understand the term, deals with all those conditions of the surface of the world which affect armies, campaigns, and battles. I do not think that it is possible to separato off from it the minor features of the earth's surface, which we more especially associate with "topography." Our doing so is, I think, an accident of military education. We most of us, in fact, learn to tako

roL. XXXYY. 
in with the eye the features of land under our eyes by actually sketching them. The consequenco is that we aro rery apt, in practice, to talk as if military geograpliy was concerned only with the greater features of a country, its military fronfiers, its great mountains and rivers, and so on, and as if the question of the character of a battlofield or the nature of a bridge were pure questions of "topography."

I am not very keen about definitions, and $I$ an by no incans sure that, as a matter of mere Greek derivation, this, my assumption, might not be shown to be wrong. What I do care about is the practical question of the effect of any separation of the two things upon' the conduct and morement of armies. I had an experience in regard to this very eaily in my military carecr which strongly impressed me. Being, I am afraid, in those days, perlaps now, not altogether ready to accept without investigation an established dictum simply because I was told it was the correct thing, I was sorely puzzled by certain explanations which were offered of a particnlar movement of Napolcon's during the 1814 campaign. I could not understand why he moved as he did. I felt sure he had some very good reason for doing it, but on the ordinary maps the -movement, with the details of-which I need not trouble sou, seemed to be wholly unaccountable. It upset my ideas of the principles on which he acted. "Tlie rery 'worthy " crammer," if I may use the term without offence, to whom I weut to study military history before going up for the : Staff College, would not hear of my objections. Nerertheless, I was not satisfied, and continued my hunt for a caiss; ;hen at last, after much resenrch, I; to iny infinito jos, discovered, I think in 'Thiers, a careful description of the nat,ire of the bridges over the Seine, the river towards which Napoleon was then moving. 'It sliowed that one pärticular bridge., was $\dot{n}$ wide' massive stone structure, practically indestructible by all army in the field; within the time Napoleon need give to liis opponents. The otheas were slight narrow wooden structures, ensily defensible, easily destructible. Instantly tho: meaning and the motivo of Napoleon's disposition of his troops stood revealed. It depended not on some elegant strategic combination such as one might makc on a sheet of paper; but upon what I shall renture to call the nilitary geography of the theatre of war.

Perháps, though it has only an incidental bearing on the subject; $\dot{I}$ may as well, as I have mentioned my "crammer," say how, from his point of view, the story ended. I sat down; a rather trembling Subaltern, to open my military history paper, with the name upon it; as examiner, of a man long since dead, whom I already knew as a very brilliant soldier, of whom I had the most profonnd awe. The first two questions that met my eyo were: 1st, a request to accoint for this particular morement of Napoleon's; 2nd, a request for a description of the bridges over the Scine. Instantly I felt that wo nnderstond ove another. Yon will; perhaps, forgive mo if I thus girc point to this particular personal illustration, because I practically havo alrays dated from that moment one ${ }^{c}$ the most valued fricndships of my life, and ccrtainly. I look upon it as 


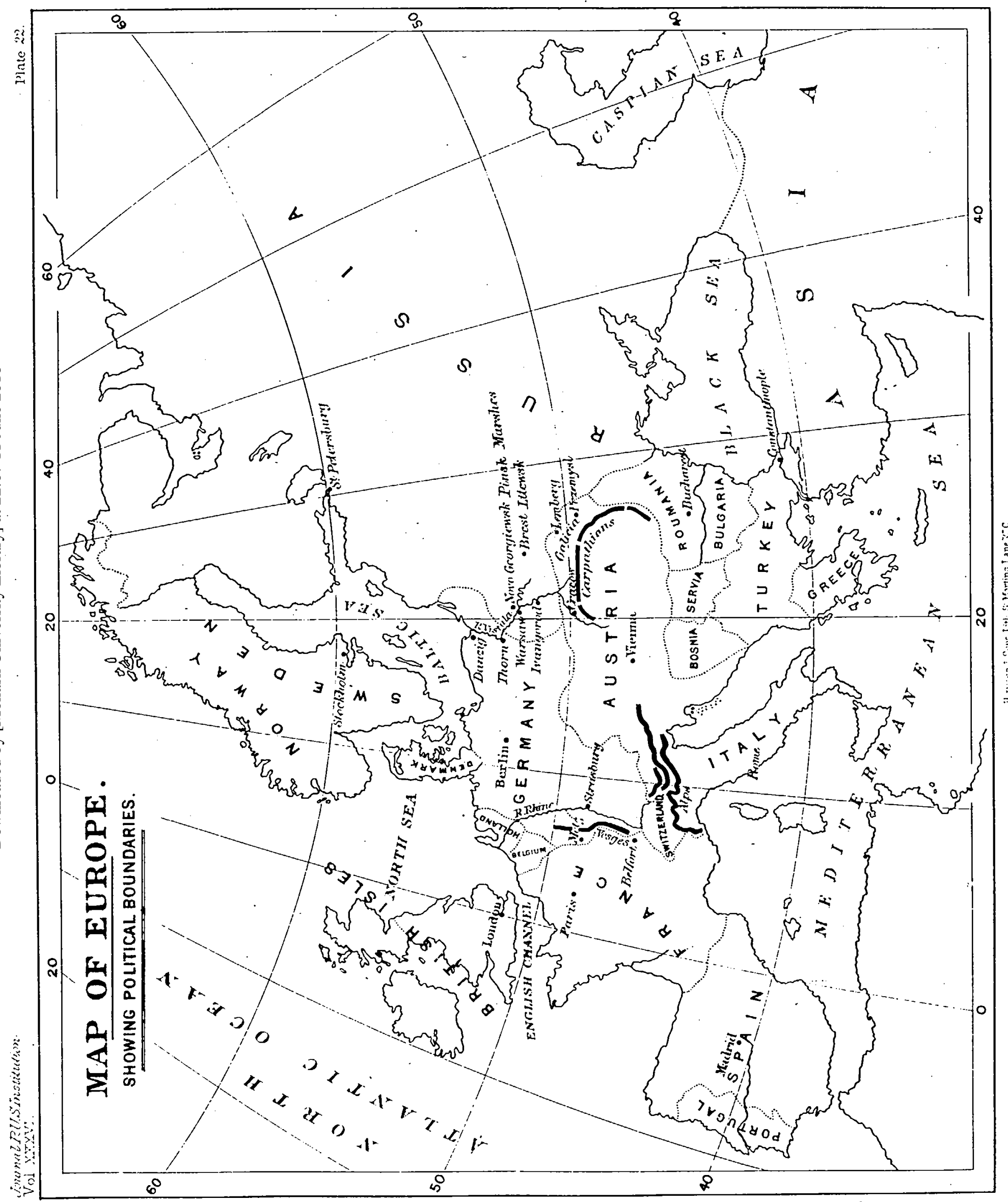


the starting. point of any confidence that I havo since then acquired in dealing with the stady of military history.

The point, then, that I wish to make is, thiat military geography; in 'all 'its: branches, whether 'it:deals with the larger' or the smaller features of the earth's surface, is 'the éssential thardmaid of 'military history; past; present, and fature. $\because$ I hardly think' that the : two subjects can ever be studied with much profit apart.from one another: It is, to my mind, a most dreary thing to study, either in the present day or the past, for instance; the military frontiers of : the different: Powers of the world; unless you: connect that stady with the historical circumstances which have affected thom and been affected by 'them, and with the opportunities which : they present to each of the Powers for : either defensive or offensive action.' Similarly, I néver could myself take much interest in the mere cnume: ration of the fortresses of a country or description of its main lines of road or other means of movement, except in connection with the history of past campaigns or as part of an analysis of : the best mode of aittacking or defending it at the present time.

-. Now; it so happens that all the greatest Continental soldiers of the last twenty years liave been at the pains to give all thoso who care to study their work, practical lessons of this kind in regard to militäry geography which are quite invaluable: I'have often said that if one conld have desired to iivent, for the purposes of military stndy; $a$ series "of imaginary frontiers with kingdoms behind them, each so varied from the other that in no two should there be a sameness in the lesson; one conld not have derised a series so instructive in their pariety as the Europcan military frontiers and kingdoms of to-day...

Each of them is based on a well-thought-out principle, in the carrying: out of which great military nations, whose: whole energy and crpacity is concentrated on readiness for war, hare each of them expended millions of money. I could not, of course, discuss these this afternoon with sufficient detail to make them intelligible to those who know'nothing about them. Bat consider how varied they are.

: France hás her great frontier girdle of fortresses; her forts d'arrêt, closing every road except at the two gaps which she has designedly left open : to admit an enemy, in order that she may there have him at her mercy; her great scheme of entrenched camps giving her both tho means of concentrating the powers of the south to strike against an invader moving on Paris and a means of aggression from her old "gap of Belfort,". now become sally-port of..Belfort." All these'aro based on the : most caroful consideration of the geography, and, if:I must make the distinction, topography, of the conntry. Behind them all-Paris the greatest fortress of the world.

Look acioss the border, what a contrast! -: Gormany now possesses, as her advanced frontier, the old French mountain $/$ barrier of tho Posges, and she defends it, how?

Study the condition of her military map, and it will tell you her strategic secrets. 'But if you are to read them aright, you must not ignore, as questions rital to military geography, the nature of the bridges cover lier great -second. military line; the Rhine, nor fail to 
watch at the railway stations the rast accomalation of what wo in England should cull sidings and platforms. She does not require, actually, sidings and platforms as we do, because her carriages givo facilities for descent between the rails for men, horses, and guns. Bat the accumulation of debarking places is enormous.

- See, too, on the map, how many minor fortresses have disappeared from it since 1870. Practically all, within the Reichsland, are either dismantled or ignored, except Strasbourg and Metz. Those, indeed, have grown prodigiously-liave become enormous entrenched camps. Her menning is on the surface. Active and rapid accumulation of troops by rnil, piroting on two great fortresses, a viver in rear of them, the possession and passage of which she guards by vely numerous fortified bridges, both for railways, carriages, and foot passengers. In rear of the great river a few great fortresses, almost all of them fortified camps, placed at her favourite point, the meeting of two great rivers, so that an cnemy who attempts to attack them is divided into three separate sections.

Look to the other side of Germany, at her system against Rnssia.

In principle it is, no doubt, the same, viz., the complete develop. ment of the facility of movement by road and railway-specially by railway -a few fortresses, very powerful, and giving command of great bridges, important lines of communication, or the only casy line of march for armies. But how different is tho country to which it is applied, and how interesting it is to sec how sho has dealt with the new geographical considerations! On this side of Europe wo aro no longer, as in Elsass-Lothringen, or, shall I say, Alsace-Lorraine, in a land of monntains, but in the great plains of the north-east. It is a land of lako and marsh, of dust and mud. Here the onc great river, which at different parts of its course is held by Austria, Rnssia, and Germany, by great fortresses, is the Vistula. It is, in fact, the one grand topographical feature of the conntry. Thorn and Dantzig, with two othor bridgo heads, givo Germany command of her part of the river. Sho has developed, as on the other side, her railways, behind and across the Vistula, into East Prussia, and between the lakes which form tho sonthern borderland of that outstretched arm of Germany sho has constructed sufficient forts to protect the gathering of her armies and to give her command of the roadway. Her frontier towards Russia, on the western border of Poland, is a land of marsh, guarded by great fortresses, which closo the only adrance of an army that would not bo slow and difficult. To gain time for active strategic morement, to kecp an alrcady slowor enemy hampered by cndless delays: these are the advantages which she sceks to gather from such geographical conditions.

Russia, on her side, presents, as I think, a somewhat deceptive character in what is suggested by tho first look at her map. If military geography were represented simply by the outlines of maps, then it would seem as if Russia dircetly threatened tho capital of Germany, which, unliko that of France, is an entirels unguarded town. But there are many conditions properly belonging to military geography which are admirably illustrated by tho contrast 
which reality presents to this appenrance. Russia can only, for the purposes of a direct invasion of Germany across' her west Polikh border, make ase of two lines of railway, one of which runs into the great German fortress of Thorn, bejond the north-west corner of Poland, while the other runs completely away to the southward point of the western border, thus largely fixing for her the possible direction of the adrance of her armies. She has not, as Germany has, railways running directly towards the common frontier of Poland and Germany. Further, I should claim that it is a necessary part of the duty of military geography to take account on the surface of the earth, not only of the actual mountains, rircrs, railways, fortresses, \&c., bat of the conditions of the "insect man" upon that surface, in so far as these affect the morements of armies. Under. that aspect the condition of the western portion of Russia is pecrliarly interesting. The Russian railways lare all had their direction deterinined by autocratic power for strategic purposes. The curious result is that those black lines on the map, which indicate for you the direction in which the railways run, represent in fict two entirely different things on the opposite sides of the frontier. Germany, like Russia, has been anxious to secure facilitics of morcment for her troops by the organization and working of her railways. But she has done this with a careful solicitude for the needs of commerce, which cnables her to work her railways with a largo staff, and a reasonable profit to the State. The consequence is that the daily working of the railways kept up by her for the ordinary purpose of commerco and traffic aro far moro effectivo means of military transport then those which have been constructed by the Czars solely for the purpose of military adrantage, altogether regardless of com. merce. I think, perhaps, it would hardly be fitting that I should here, and to you, speak fully of those conditions of the popalation of Poland and of the ueighbouring provinces, which will undoubtedly, in the event of war, very largely affect the morements of the opposiug armies. But $I$ want to note in passing that, as such conditions as these must be tuken into account in any strategical examination of the theatre of war for the purpose of determining beforchand what operations are to be carried on in it, they are for our purposes an essential part of military geography, though no doubt the scientific people might object that these were properly ethnographical considerations.

The grcat system of fortresses by which Russia holds Poland presents characteristics essentially determined by the conditions of the military gcography of tho region, which aro entircly unlike those of either France or Germany. There is a certain space of gronud held by the fortresses of Irangorod, Warsaw, and Novo-Georgicwsk, which has always, from the nature of the passages over the rivers which it secures, given to its possessor command of the muddy plains of Poland. The great furtress which stands back from these-Brest Litcwsk-is necessary to keep up the connection with the grcat mass of Russian territorg. The enormous marshes which separato RusBia from the Polish region present so great a difficulty for the morement 
of her troops, that it is cosential to have a great fortress at the point where the one railway, across the marsh eastwards into the heart of Russia, meets the various communications which run in towards Poland from the regions to the north and south of the marsh. Behind this frontier region the vast distances, the slender modes of communication which the map of Russia represents determine now; as they have determined in former days, at least in a very important degree, the strength and weakness of Russia.

The geographical characteristics of Austria are again in many reepects rery distinct frum any of these that I hare sketched hitherto. It is essentially her geograpbical position which is at once her danger and her strength. The formidable mountain region of. Transylrania, where the Hungarians in 1848 fought so magnificent a series of battles, gires now to the dual Monarchy, as in the dajs of the Crimea, the complete command of the approach of Russia upon Constantiuople. If she stood alone there can be no doubt of the dangers which this powerful weapon of offence would entail upon her.- It makes hor the chief obstacle to all adrance torards Constantinople.

The northern frontier of Austria as towards Russia presents tho peculiarity that the border province of Galicia lies betiseen the Vistula and the Carpathians, whilo a series of rivers of some im. portance, notably the San, the Wjiloka, and the Donajec, run down from the mountains into the Vistula. No country has in former jears elaborated a system of fortresses for the possession of a kingdom more complete than that which Austria carried out in Lombardo-Venetia. Along her Galician fronticr, on the contrary, it is only of late years that sho has taken to constructing rery solid works of permanent fortification. It will show, perhaps, the intimate connection between military history and the military map of a country of which I have spoken, if I note that the fact that for many years Austria bad relied upon tho friendship of Russia, together with the embarrassed state of her own finances, indaced hor in Galicia to aroid committing herself to the expense of permanerit fortifications. When she proroked Rassia in 1854, it becamo necessary to construct rast temporary ficld works. "This had been her resource, in fact, whenever an emergency pressed upon her. Now works of field fortifications, relatively economical and effoctive for the moment as they are, have the disadvantage that they do not remain effective for rery long. Hence practically, during the present period of Faropean politics, when Austria found herself face to face with a bitterly hostile Russia, and when her ally Germany required that she should set her house in order, so that the alliance might be effective without throwing an undue strain upon Germany, Austria found herself with practically the whole work of making a fortified fronticr in Galicia to be began with a clear ficld. She appears to have fortified the Carpathians with certain works tending to at least delay the morements of an army by the only passes which are arailable; to have secured the command of the most important part of the Vistula within her region by making a first-class fortress and entrenched cainp at Cracow, and by securing as a second pirot 
for the morement. of her armies powerful works at Przemysl and Lemberg. . These works, together with that necesary accompaniment of any modern. system of national defence, namcly, a great development of her railway system for military purposes, have been the changes in her military map ; in the stady, that is, of her military. geography, which her present political situation has entailed upou Austria. There can pe no doubt that the broad butlines of what she designs in view of future war, may in her case; as in others, be traced in what she has done.

Of the opportunities presented to her for offensive war, carried ont in alliance with Germany, I have, I think, indicated as much as space will permit me in what I have said already of the frontiers of Russia and Germany. Had she to defend Galicia, there can be little doubt that she would not fall back by the Carpathians, but, employing merely a retaining force $w$ ithin the passes, would take up as successivo lines the San, the Wysloka, and the Donajec, threatening a flank attack upon any Russian army that should attempt to cross the Carpathians ignoring the force in Galicia. Thus this frontier presents peculiarities both in its military geography and in the strategical methods which are determined by it, essentially different from any of those wo hare had to consider elsewhere.

I might enlarge, if time permittcd me, upon the contrast presented by the territorial frontier of the fifth great Continental Power-Italy. She, like Germauy, to the west has as her laud frontier a grent mountain barricr. But tho snow-clad Alps are a mountain frontier of a rery different character from tho Vosges. Even here the student of military gcography will find a now example worthy of altogether independent study in point of principle from any of the rest. It has been treated, moreorer, with that freshness and originality which one might expect from the soldiers of a joung , conntrs, full of national cnthusiasm, and unhampered by the traditions of the past. But the frontier of Ytaly presents. another featuro far more interesting to us as Englishmen. Italy possesses a seaboard of such an enormous cxtent in proportion to her territory, that for her tho important frontier is less hor great mountain barrier than her coast. - All her statesmen and: her soldiers, at least as much as her sailors, feel that it is the seaboard of Italy which it is all-important todefend. -Hence the relatively great development of the Italian Fleet, hence the anxious desire to maintain those cordial relations with a great naval Power which happily do not depend only upon mere considerations of mutual interest as between England and Italy, but upon those much despised; but all-important, factors of so-called sentiment; upoin the learty sympathy. with which from the first England has -watched the derelopment of the youngest and oldest nation in Europe, and the complete recognition of that sympathy by Italy.

There can be no doubt that for us, the rise of the Italian Power more than any other event of our times has changed the centre of interest of the military geography of the world. for Englishmen. The sea-washed shores of the outer world must always be our closest points of coutact with it. .I'he enormous development of our 
Colonial Empire, due mainly to our dominion over-the sea, naturally. caused during rnany years of the present century the attention of Englishmen, and therefore of English soldiers, to be directed towards our own parts of the world almost to the exclusion of Europe. But two erents, of which the rise of Italy is the first, and the approach of a great Luropean Power towards the fronticr of India is the second, hare changed all that for those who bave carefully studied the present signs of the timcs. I hardly venture, towards the close of my lecturc, to touch upon all the problems which aro iurolred in the military geography of our great Asiatic Empire. But I think it will be sufficient to say, first, that Russia is now so near to us in India that we can hardly any longer regard ourselres as having the sen as our sole important frontier, at least as long as we consider, as most Fnglishmen do, that the defence of the Indian frontier is an essential part of the defence of England; socondly, that she is still so distant from our Indian Empire that it is extremely difficult for us, withous great military risk and without handing over to her many of the advantages which the geographical situation at present posscsses for as, to forbid her approach in a most dangerous manner step by step towards our frontier. Therefore it is that it becomes exceedingly important to us to inquire whether there may not be geographical conditions in burope which tend to redress the balance in Asia. I certainly think that there are. The rise of the Italian kingdom with its great seaboard frontier is only one of them. The fact that Italy is an essential constituent of an alliance in which two Powers great as military States, and relatively inferior as naral ones, bear the mose important parts, make the means by which alone Italy can be made an effectire military member of the alliance as important to them as to her. But eren more important to them is the essentially seaboard frontier of Denmark, aud the extent to which in all movements of troops between Russia and Germany the whole advantage rests with the Power that commands the Baltic.

'The full consideration of ail these questions is a matier of the actual study of military geography. They could not be dealt with in a single lecture in which it has been my object rather to take the subject which the Council has as8igned me: to show the scope, the rariety, and the importance of its interest, and to urge its careful study upon all soldiers, statesmen, or other Englishmen who may have to deal with the problems of the fature as they concern onr country. For the reasons which I explained in the beginning of this lecture, I have preferred to take the method of illustration rather than that of an abstract setting forth of the principles of the stady of military geography. Even for that purpose of illustration, I might have adopted a different method. I might hare taken any one or more of our modern campaigns, or of the greater contests in Europe or America, and hare shown how a military analysis of the geography of the country was an essential element in determining the conduct of each of them. But on the whole it seemed to me that at the present moment the particular illustrations that I havo chosen would bo the more interesting, and I car only hope that they will havo 
fulfilled what I take it was the parpose of the Council, that of drawing attention to the vital importance of this most interesting study.

Dr. MAGirs : It appears to me that it would be a pits there should be no dis. cuseion following upon ouch a rery interesting lecture; and, accordingly, though a joung member of tbis Institution, I truat jou will sllow me to say a few words, not by way of criticion, but rather by way of supplement to Coloncl Maurice's lecture. I can scarcely imagine any more intereating situations to the theoretical student of history, or to the practical student of the art of war, than those which Colonel Maurice lias so ably brought before us. MF nonder is that such a large proportion of soung English Officess and gentlemen are allowed by their teachers and others to comc to somewhat mature age without haring some better hnowledgo of geography, which appearn to me to be the basis of the knowledge of history, and, indeed, with so rers little knowledge of history itself. I hope, however, that when gentlemen like Colonel Maurice make such remarls as those that appear at the end of his lecture, the attention of the authoritic will bo forcibly directed to taking stops to secure that Englieh eduoation of the future will not be 80 defective in these material matters as it now is. I cannot imagine any more interesting way in which a young man erch for amuscment, not to speal $\alpha$ profit, can spend his time than by taling up a good map and on it following somo etriking campaign. Unfortunately, one of the maps exbibited to-das is difficult to sec from this distance. It is a rery raluable map carefully constructed, I beliere, bj the eminent geographers in the employment of Mr. Stanford, and it shows at a glance the great lincs of inrasion, not merely that exist now, but that bare cxisted in all sges. I was watching that map the other day when reading some ancient history, and it was astonishing to see that the rery routes indicated by Colonel Maurice wero the routes taken, ss far as tradition teaches $u s$, by the terrible insasions that deatrojed the Roman Empirc. The map is an crceedingly good one, and if it could be made twenty times larger, it would become inraluable for lectures on military history. Iooking at it, one will sce that on starting from Ruseia, as Colonol Maurice indicated, and trying to get to sincient Gaul or Ital 5 , or into the countries around theso old cbjects of barbaric grecd, the inrading hordes were hampered by the same lind of obstacles that would now hamper inrading armies. When thes got round tho Carpathians to the south or the north, and then had to get down into Italy, they found great rivers and the mighty masses of the Alp blocking their way. Traneslrania snd the Banat and the Valley of the Drare were to the strategists who liad to defend Rome nnd Byzantium what they now are to Turks and Austrians and modern Italy. The lecture: said he would illustrate theso matters from current history, and could equally display them by reference to the past. It mould be particularls interesting to seo that in part history all the great military morements, backward and forward, ourged along the Valley of the Danube towards the Rhine, or, taking a side direction, fot inrolred in tho Valley of the Po. For instance, Napoleonic times, taking the cempaign of 1796, from the Main to Bohemia, and the Niddle Bhine to the Isar, and the Riviera on to the Drere; and spain, in 1800, Morcau from the Rhine betreen the Lake of Conatance, and Napoleon across the Alps and across the Po; and, again, the campaign of 1805, when Napoleon started from the Mrain and the Rhine, and at the eame time Massene was moring to the Italion Quadrilateral. In 1809 and 1814 alco, it is particularly interesting to see hor the operations in the river ralless, castrard and westward respectirely, were linked by the gaps in the mountains: for example, by the passes in the Tyrol and by the violation of Switzerland's neutrality. Theso are ouggestions that mercly camo into my mind whilat listening to the admirsble address of Colonel Maurice. Many other suggestions might be giren if one had time, but I think I lare said enough to show that we are grateful to the Colonel for stirring up memories of the past as well as for his гiens about the problems of the future. I would further ask the lecturer what he meane by stating, with regard to Italy, that the examplo quoted "las been treated moreorer with thet freshnese of originality which one might cspect from the soldiers of a joung country full of national onthusiam and unhampered by 
the treditions of the pat." I should like to know if Colonel Maurice refers to the most instructire treatise on Stratcgic Geography by Colonel Sironi.

Colonol MLERICE: I did not refer to anj onc author." I was thinking of sereral. It always secms to me one of tho most interesting facts we hare to do with in connection with the Italian Army that thes haro entered into these questions unlampercd by those traditions of the past which, to a certain extent, tio us all-that the Italians, coming in with a brend new annj, naturally deal with these questions with a perfectly unbinged mind, and that all that has been done in that line secms to hare been thought out by themoelves and not taken from the mere forms of France, Germans, and Kuseia, or from things ss they sire.:

The Chalrysx: If no one is ansious to ask anj further questions of Colonel Maurice I will only renture to ens, on my own behslf, bow much gratified I hare becn to hear the lecture. I fecl that it is a subject which cannot be too prominently brought to notice. The study of Military Geography is one that has this adrantage, that it continues from all ages; the student of Military Goograply is not like the mun who, haring learued the art of uing the bow and arrow, finds that le las lost all his previous training. when ho has to learn the art of making gunpowder. The same considerations which were alluded to by Dr. Maguire prerailed in the inrasions of these countries a thousard. years ago as they do nor. 'Thereforo it is a study which has a continuity about it which is rery adrantageous to the student. It was not rery. long ago that a suggestion was made to me in the Department orer which I pneside at the Kar Office, that instead of teaching soldiers, or requiring them to learn history and. geography at the Arms Schools, we should teach them afilitury Bistory and Military Geograplyy. I felt bound to say that I thouglit that it rould be dificult to study Military History and Military Geography without haring some acquaintance with general history and general geography in the first place, and I think we may say that that applies rerJ specially to geography, bccauso Jilitary Gcography is really the application of the geography of the countrs in 20 far as it concerns the exigencies of campaigning. I am afraid it is a subject which is somerhat neglected not only in the Army, but in all clases. I may refer to what was written for is the other day in the "United Serrice Magazine" by a gentleman who has had cxperienco in training candidatcs for tho Army, in which he gires sereral somerhat ludicrous instances of the ideas which some of his pupils had of history and of geography. I think that thicir failuro to understand properly the sereral points was due more to defects in their general cducation, than in any training thes mas harc had for the Armj; because the mistakes thes made would harc been as regrettable in a joung mercliant or a young lanser as in a joung soldier. I need not saj more, except to ask jou to allow me to offer to Colonel Maurice on jour behalf the thants of the. Institution for his interesting lecture. 